\title{
Cellular Catabolism of Heparan Sulfate Proteoglycans
}

\author{
ヘパラン硫酸プロテオグライカンの細胞内代謝
}

\author{
Yanagishita, Masaki \\ Department of Biochemistry,Tokyo Medical and Dental University, Faculty of Dentistry \\ Yushima, Bunkyo-ku, Tokyo 113-8549, Japan \\ FAX:81-3-5803-0187, E-mail: m.yanagishita.obch@dent.tmd.ac.jp
}

Key Words : cell surface heparan sulfate, endocytosis endosome, heparanase, matabolism

\section{A. Introduction}

Heparan sulfate proteoglycans (HSPGs) are widely distributed among animal cells, as a basic component of cell surface molecules and as a major constituent of basement membranes. Important molecular characteristics of HSPGs reside in their capacity to specifically interact with many proteins and to regulate their biological activities. Those molecules which can interact with HSPG include heparin-binding growth factor family molecules, such as fibroblast growth factors; molecules involved in cell-cell or cell-extracellular matrix interactions, such as laminin and fibronectin; pathogens, such as viruses, prion and plasmodium. The cell surface, where cellular recognition of signals from extracellular space occurs, is a strategic location for HSPGs to exhibit their diverse molecular interactions. Thus, regulatory mechanisms involved in expressing heparan sulfate proteoglycans onto the cell surface, in maintaining them on the cell surface in close proximity to specific cell surface structures and molecules, in shedding molecules from the cell surface, in controlling endocytosis, critically affect biological functions of HSPG. Among these regulatory mechanisms of HSPG metabolism, this minireview focuses on the significance of cellular catabolism of HSPGs and discusses their unique intracellular catabolic pathways.

The metabolism of HSPGs, especially their intracellular catabolic processes, has been studied mostly using model cell culture systems (1-31). This is mainly because studies using whole animals or organs do not easily allow experimental designs to analyze details of molecular metabolism. Typical experimental protocols studying metabolism of cell surface HSPGs have used cell culture systems in combination with metabolic labeling of proteoglycans with $\left[{ }^{35} \mathrm{~S}\right]$ sulfate as the precursor, and with various chase protocols. Such approaches have several advantages; (i) proteoglycans can be labeled with relatively high specificity and the species of proteoglycans can be separately analyzed by specific enzymatic digestion, chemical degradation and various chromatographic procedures, (ii) $\left[{ }^{35} \mathrm{~S}\right]$ sulfate added to cell cultures rapidly reaches a metabolic equilibrium with intracellular PAPS (phosphoadenosine
A. はじめに

ヘパラン硫酸プロテオグライカンは細胞膜の基本成分とし て多くの哺乳動物細胞の表面に存在し、また基底膜の主要構成 成分の一つとして広く生体内に分布している。本特集の他の論 文で詳しく述べられるように、ヘパラン硫酸プロテオグライカ ンの分子機能の特徵は、多くの生物学的活性物質と特異的な相 互作用を示すことによりこれら分子の機能発現調節をしている ことである。例えば、線維芽細胞成長因子(FGF)などへパリン結 合性成長因子と呼ばれる一群の成長因子や、細胞間、細胞 - 細 胞外マトリックスの相互作用に関与するうミニン、ファイブロ ネクチンなどの分子群、ウィルス、プリオン、プラスモデイウ ムなど外来性病原体など広範にわたる分子と特異的な相互作用 を示し、これら分子の生物学的活性発現機構の調節に関わるこ とが知られている。このようなへパラン硫酸プロテオグライカ ンの生物学的機能を考える上で、この分子が細胞表面という細 胞認識機構上重要な部位に存在することは必須な条件であり、 このために細胞が細胞膜上への発現調節、細胞表面での代謝回 転調節、特定の細胞表面構造·分子との相互関係制御、細胞表 面からの放出、細胞内への取り込みといった機構を使ってへパ ラン硫酸プロテオグライカンの細胞表面での局在および濃度調 節を行っていることを理解することが重要である。本稿ではへ パラン硫酸プロテオグライカンの代謝過程の中で、特にこの分 子の持つユニークな細胞内分解過程に焦点をしぼって議論する。

細胞膜ヘパラン硫酸プロテオグライカンの代謝、特に細胞 内代謝は、いくつかのモデル実験系で主に細胞培養を用いて研 究されてきた(1-31)。これは動物全体や臟器を使った実験系で は詳細な分子の挙動を追跡することが困難なためである。通常 用いられる実験方法としては、培養中の細胞が生合成する細胞 膜型ヘパラン硫酸プロテオグライカンを $\left.{ }^{35} \mathrm{~S}\right]$ 硫酸などの放射性 前駆物質で代謝的に標識し、この代謝標識されたプロテオグラ イカンを経時的に追跡することで細胞内でのプロテオグライカ ン分解過程を研究する方法である。このような方法の利点とし ては、(i)プロテオグライカンが $\left[{ }^{35} S\right]$ 硫酸によりかなり特異性が 高く標識され、分析の段階で特異的分解酵素や各種クロマトグ ラフィー法を組み合わせることで各種のプロテオグライカンの 分離が可能であること、(ii) 細胞内硫酸転移反応において直接の 硫酸供与体となる PAPS (phosphoadenosine phosphosulfate) は短 
phosphosulfate), the immediate sulfate donor for intracellular sulfotransfer reactions. The later allows labeling of proteoglycans within a short period of time, typically within less than a few minutes. This, in combination with other experimental designs such as pulse-chase protocols and subcellular fractionation procedures, enables experimentalists to explore detailed behavior of HSPG during their metabolic processes. There are some shortcomings with $\left.{ }^{35} \mathrm{~S}\right]$ sulfate labeling procedures, however. It only labels the glycosaminoglycan component of proteoglycans. Therefore, fate of other proteoglycan components, such as core proteins and oligosaccharides, cannot be directly deciphered. Results from many such metabolic studies of proteoglycans have shown variability based on the differences in the experimental procedures and cell systems used. However, some clear common themes of HSPG metabolism seem to appear with variations. In this article, I will discuss on the intracellular metabolism of cell surface HSPGs mainly based on one of the most extensively studied system using rat ovarian granulosa cell cultures, and discuss results from other systems as necessary.

\section{B. Localization of Heparan Sulfate Proteoglycans on the Cell Surface}

Interactions of HSPGs on the cell surface with other molecules and with specific cell surface structures play crucial roles in their biological functions. Therefore, HSPG may be associated with some specific cell surface locations. For example, syndecans have been reported to reside mainly on the basolateral surface of mammary epithelial cells (29), and glypican, which is attached to cell membrane through a GPI (glycosylphosphatidylinositol)-anchor, has been predominantly found on the apical surface in some cells (30). However, further studies are required to strengthen the generality of these findings. There are other reports suggesting the association of HSPG with some cell surface structures; an electron micrographic observation localized HSPG on microvilli (23), a micrographic study suggested the presence of HSPG at the focal adhesion site and implicated in signal transduction (32). It has been speculated that glypican, like other GPI-anchored proteins, may be concentrated in a specific cell surface structure called caveola. However, since some cells which has few caveola are known to synthesize glypican (Hiscock, D. personal communication), the relationship between glypican and caveola remains unclear.

\section{Endocytosis and Release from the Cell Surface}

A number of studies have measured the metabolic turnover rate of cell surface HSPGs; they are metabolized actively and typically have half-lives of 3-20 hr on the cell surface. They are removed from the cell surface mainly by endocytosis. The mechanisms involved in the endocytosis of HSPG are
時間(数分以内)で細胞外硫酸と平衡化されるためごく短時間の パルス標識が可能なことである。これらの代謝的標識法の特徵 と、適切なパルス - チェイス実験法、細胞分画法を組み合わせ ることで、プロテオグライカンの詳細な細胞内代謝過程が明ら かにできる。一方、この方法の欠点の一つとしては、 $\left.{ }^{35} \mathrm{~S}\right]$ 硫酸を 使った代謝標識法ではグライコサミノグライカンのみが標識さ れるため、プロテオグライカンのコアタンパクやオリゴ糖成分 の代謝を追跡することが困難なことである。使用された細胞の 種類により代謝過程が異なることや、異なる実験手技が用いら れるため、これまでに報告された実験結果は一様ではないが、 多くの細胞に共通した基本的なへパラン硫酸プロテオグライカ ンの細胞内代謝過程、細胞種による特殊性などを観察すること が可能である。本稿では、筆者らがこれまでに報告したラット 卵巣顆粒膜細胞の細胞培養系を用いた実験からのデー夕を中心 に、ほかの細胞系からの報告を比較をしながら議論を進めたい。

\section{B. ヘパラン硫酸プロテオグライカンの細胞表面での局在}

細胞膜ヘパラン硫酸プロテオグライカンが細胞膜上で特徵 的な部位あるいは特殊な構造と関連して存在することはその機 能を果たす上でとりわけ重要なことである。例えば乳腺上皮細 胞ではシンデカンが主に細胞膜の側底部に存在する(29)という 報告や、GPIアンカーを持つグリピカンが頂膜側に多く存在す る(30)という報告もあるが、これらの観察は必ずしも一般的な 規則ではないかもしれない。さらに特殊な細胞膜構造としては、 ヘパラン硫酸プロテオグライカンが微絨毛に多く見られたとい う電子顕微鏡像(23)や、focal adhesion site に集中していてシグナ ル伝達に関与している(32)という所見もあるが、その一般性は また確立されていない。グリピカンは他の GPIアンカー型タン パクと同様に caveola 構造に集中している可能性も考えられる が、caveolaをほとんど持たない細胞にもグリピカンが多く存在 している場合もあり(Hiscock, D. personal communication)、今後 の検索が必要である。

\section{C. エンドサイトーシスと細胞外への放出}

種々の細胞培養系を使った測定では、細胞膜へパラン硫酸 プロテオグライカンは細胞表面上で通常 3 20時間の半減期で 代謝され、その大部分はエンドサイトーシスにより細胞内に取 り込まれる。エンドサイトーシスの過程はヘパラン硫酸プロテ オグライカンの細胞膜との結合形式(細胞膜貫通型のコアタンパ 
likely to differ based on their cell membrane anchor structures, i. e., whether they have transmembrane core proteins or GPIanchors. In fact, transmembrane and GPI-anchored HSPGs present on the same cell have been shown to have different kinetic parameters for their endocytosis (8), suggesting that each has a distinct endocytotic mechanism. As detailed below, they also have different intracellular degradation pathways after endocytosis (8). In either case, cell membrane anchored HSPGs are endocytosed as a part of plasma membrane. Since the average turnover rate of membrane lipids on the cell surface is usually less than $1 \mathrm{hr}$ (T1/2), proteoglycans can be considered as molecules actively excluded from the bulk flow of membrane lipids. It has been suggested that glypican may be released from the cell surface by a GPI-anchor specific phospholipase and bind to a cell surface receptor before its endocytotic uptake (31). However, it is not clear at present if such an endocytotic mechanism is widely observed.

Since HSPGs can specifically bind to a number of proteins, it is conceivable that these proteins may be carried along with HSPGs when they are endocytosed. One good example for this possibility is that HSPGs functions as endocytotic receptor for follistatin (33) and regulating its extracellular concentration.

As discussed above, the major metabolic pathway for cell surface HSPG which accounts of the disappearance of the molecule from the cell surface involves endocytosis. However, some HSPGs are also known to be shed into culture medium. Whether this shedding phenomenon reflects secretion of HSPG in physiological conditions or a cell culture artifact, is not entirely clear at present. There is an observation that transmembrane and GPI-anchored HSPG have distinct kinetics of shedding (8). For the shedding of HSPG which has transmembrane core protein, a part of the core protein has to be cleaved (see figure below, step 9). A proteolytic cleavage site, consisting of
クを持つか、GPIアンカー型か)により異なることが予測される。 事実、同じ細胞上にある細胞膜貫通型と GPIアンカー型へパラ ン硫酸プロテオグライカンのエンドサイトーシス動態の違い(8) が報告されている。また後述するように、エンドサイトーシス 後の細胞内運送経路にもそれらの細胞膜結合機構の違いにより 大きな差のあることが知られている(8)。いずれにしても細胞膜 に結合したへパラン硫酸プロテオグライカンは細胞膜構造の一 部としてエンドサイトーシスされることになる。細胞膜脂質全 般の代謝回転速度が 1 時間足らずの半減期を持っていることか ら考えると、ヘパラン硫酸プロテオグライカンの細胞表面上の 半隇期が 3 時間以上であることは、この分子が細胞膜脂質全般 の流れから除外(exclude)されていると結論することができる。 この他、GPI アンカー型のヘパラン硫酸プロテオグライカンが phosphatidylinositol-specific phospholipase C (PI-PLC)により細胞 膜から切り離され、この断端が細胞表面にある受容体に結合し てエンドサイトーシスされるという報告(31)もあるが、これも GPIアンカー型のヘパラン硫酸プロテオグライカンの一般的な エンドサイトーシス機構かどうかは不明である。

ヘパラン硫酸は多くのタンパクと特異的な結合をするた め、ヘパラン硫酸プロテオグライカンがエンドサイトーシスさ れる際にすでに結合したタンパクを同時にエンドサイトーシス する可能性がある。事実、ヘパラン硫酸プロテオグライカンが follistatin どをリガンドとしてのエンドサイトーシスレセプ ターの役割をはたし、follistatinの濃度調節をしている例も知ら れている(33)。

上記のように通常細胞膜ヘパラン硫酸プロテオグライカン はエンドサイトーシスにより細胞内に取り込まれるのが主な代 謝経路であるが、細胞培養を使用した実験系では一部の細胞膜 ヘパラン硫酸プロテオグライカンが培養液中に放出されること がしばしば見られる。これが生理的なプロテオグライカンの分 泌様態であるのか、細胞培養条件での人工的な現象なのかにつ いては明らかではない。膜貫通型のコアタンパクを持つシンデ カンファミリーのプロテオグライカンと GPIアンカーを持つグ リピカンファミリーのものではその分泌動態が異なることが知 られている(8)。膜貫通型のものが分泌されるためにはタンパク 分解酵素によるコアタンパクの分解が必要である。コアタンパ ク中の酵素分解部位に関して、細胞膜付近の塩基性アミノ酸の

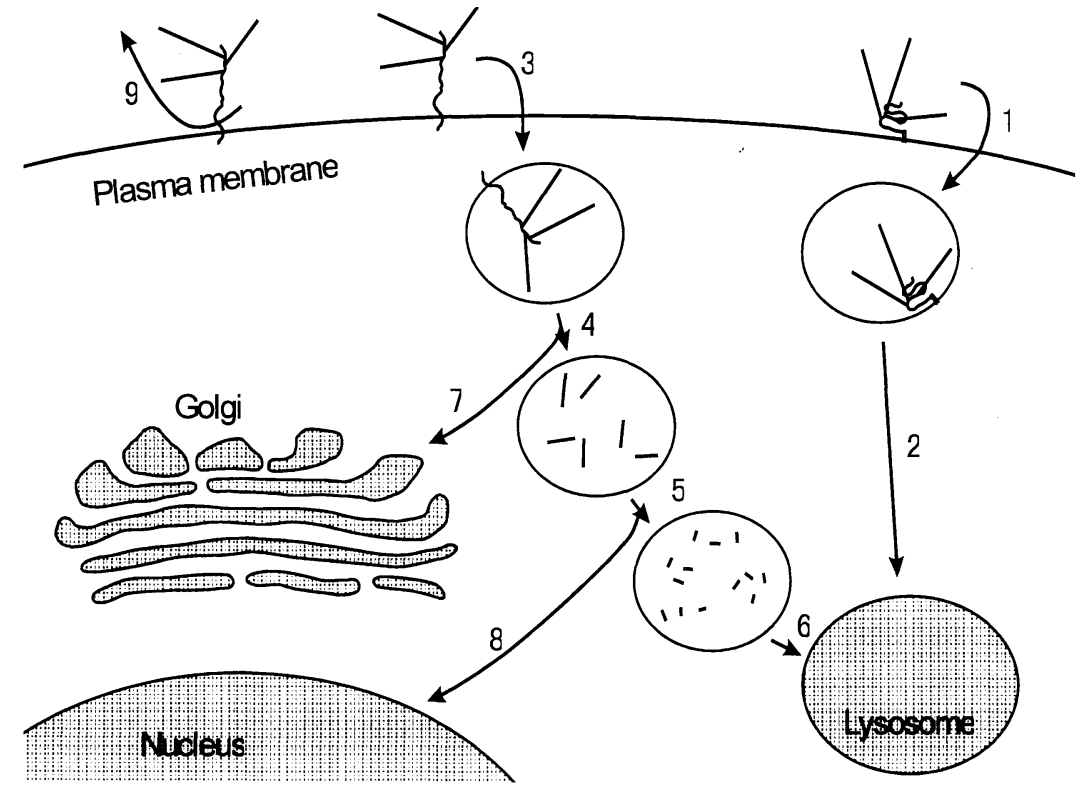

Fig.1. A schematic model for intracellular degradation of cell surface HSPGs in rat ovarian granulosa cells. GPI-anchored HSPG undergo rapid degradation (step 1 and 2, also referred to as degradation pathway I in other papers) without generating detectable degradation intermediates. HSPGs with transmembrane core proteins follow slow, step-wise degradation processes (steps 3-6) which generate distinct degradation intermediates. See text for details. 
Trends in Glycoscience and Glycotechnology Vol.10 No.52 (March 1998) pp.57-63

basic dipeptide near the plasma membrane in a syndecan structure, has been proposed because of it resembles to trypsin-susceptible peptide sequence (17). However, this may not be the case since HSPG belonging to syndecan family but does not have this sequence can also be shed equally well in the same cell. Epidermal growth factor and thrombin have been shown to enhance shedding of HSPG from the cell surface in endothelial cells (17). Wound fluid has been shown to contain significant amounts of HSPG which may be involved in the mechanism of would healing. For GPI-anchored HSPGs, the presence of a phosphatidylinositol-specific phospholipase has been postulated (31) but remains elusive.

\section{Intracellular Degradation}

HSPGs undergo unique intracellular degradation involving kinetically distinct multiple pathways after they are endocytosed from the cell surface. Two such pathways have been clearly identified in granulosa cells (Fig. 1) (1-9), and similar degradation processes have been observed in other cells as well.

\section{D-1. Rapid Degradation Pathway (Degradation Pathway} I)

Some HSPGs are rapidly transported to lysosome and degraded after endocytosis (step 1 and 2 in the figure). Kinetic parameters of transport and degradation for this pathway resemble those for molecules which undergo generally observed receptor-mediated endocytosis. In this case, HSPGs are completely degraded in lysosomes within 20-30 minutes of endocytosis, and no degradative intermediates can be detected. This is clearly different from those observed for the other HSPG degradation pathway (degradation pathway II) described in detail below, where degradative intermediates are clearly generated. Differences in core protein structures appear to determine separate intracellular transport pathways eventually leading to lysosomes. In fact, in granulosa cells, glypican family HSPGs are degraded by the degradation pathway I, and HSPGs with transmembrane core proteins undergo pathway II degradation (see below). Although the reasons why HSPGs with different membrane anchoring mechanisms follow distinct degradation pathways are not clear at present, they probably reflect segregated functions of HSPG species. Chloroquine totally blocks lysosomal degradation (step 2), but only slightly reduces endocytotic process (step 1).

\section{D-2. Slow and Step-wise Degradation Processes Involving Heparanase (Degradation Pathway II)}

Some HSPGs undergo extensive degradation in their core protein moiety and release free HS chains (step 4) shortly after endocytosis (step 3). During this degradation step, a heparan sulfate-specific endo- $\beta$-glycosidase (heparanase, 34 45) cleaves HS chains and generate fragments with MW $\sim 10,000$ (c.f., average MW of intact HS chains is $\sim 30,000$ ). dipeptideがそのトリプシン感受性コンセンサス配列から疑われ たが、その証明はない。しかもこの配列を持たないプロテオグ ライカンも同様に分泌されることからこの仮説は疑問視されて いる(17)。GPIアンカーを持つものに対しては内因性の PI-PLC が作用してプロテオグライカンを細胞膜から切り離すことが報 告されている(31)。上皮細胞成長因子(EGF)やトロンビンがプロ テオグライカンの分泌を増すことや、創傷中の滲出液にへパラ ン硫酸プロテオグライカンが著明に分泌されることも知られて おり、創傷治癒機転などとの関連も推察されている(17)。

\section{D. 細胞内代謝分解過程}

ヘパラン硫酸プロテオグライカンはエンドサイトーシスさ れた後ユニークな細胞内代謝を受ける。更に、同一の細胞内で いくつかの異なった代謝経路を持つこともへパラン硫酸プロテ オグライカンの細胞内代謝過程の大きな特徵である(図1)。へパ ラン硫酸プロテオグライカンの代謝過程はおもに細胞培養系を 用いた放射能標識実験で研究され(1-9)、以下のように要約され る。

\section{D-1. 急速な細胞内分解経路(第I経路)}

ヘパラン硫酸プロテオグライカンの中には、エンドサイ トーシスを受けた後短時間のうちにライソソームに輸送され分 解を受けるものがある(図中第 1 および2段階)。このような動態 のエンドサイトーシス $\rightarrow$ サソソームへの輸送は、細胞膜受容 体に結合する多くの分子がたどる経路(receptor-medicated endocytosis)に似ている。この場合、エンドサイトーシスされた ヘパラン硫酸プロテオグライカンは急速に(エンドサイトーシス 後の半減期約 20３0 分)分解されるため、中間分解産物は検出 されない。この動態は以下に述べるへパラネースの関与した第 II 分解経路とは大きく異なり、エンドサイトーシスの時点から 異なった機構で分子の輸送経路が規定されていることが推察さ れる。顆粒膜細胞においては GPI- アンカーを持つグリピカン ファミリーに属するヘパラン硫酸プロテオグライカンは第 I 経 路で分解され、細胞膜貫通型コアタンパクを持つ(シンデカン ファミリー)ヘパラン硫酸プロテオグライカンはヘパラネースの 関与する第II 分解経路で細胞内代謝をうける。これは異なる細 胞膜アンカー構造によりエンドサイトーシス機構が明らかに分 別されている証拠である。この分別がどのような細胞機能的意 義を持つかに関しては不明であるが、例えばGPI-アンカー型の ヘパラン硫酸プロテオグライカンが caveola など細胞膜の特殊構 造に関連し、その部位での分子機能調節などに関連しているた めかもしれない。細胞内小器官の酸性化を阻害するクロロキン などの薬剤は、この分解経路第 2 段階のライソソームにおける 分解を完全に抑制する。クロロキンはエンドサイトーシス自体 には著明な影響を与えない。

D-2. ヘパラネース(heparan sulfate specific endo- $\beta$ glucuronidase)の関与した段階的分解経路(分解第 II 経路、遅延 型経路)

エンドサイトーシスを受け細胞内に取り込まれたへパラン 硫酸プロテオグライカンのあるものは(図の第3段階)、そのコア タンパクが急速に分解され、ヘパラン硫酸鎖は遊離の糖鎖とな る(図の第 4 段階)。このコアタンパク分解とほほ同時にへパラ ン硫酸鎖は特異的な endo- $\beta$-glucuronidase(ヘパラネース)(34- 
Trends in Glycoscience and Glycotechnology Vol.10 No.52 (March 1998) pp.57-63

These processes are not inhibited by chemicals which interfere with the acidification of intracellular compartments (e.g., chloroquine), suggesting that the cellular compartment where this degradation occurs is at neutral $\mathrm{pH}$ (such as in endosomes). The heparanase enzyme involved in this degradation has an optimum $\mathrm{pH}$ near neutral, also supporting that the process occurs in a prelysosomal, neutral environment. Some evidence suggests that proteolysis precedes the endoglycosidic cleavage and that these two events occur sequentially in functionally segregated compartments but not concurrently in the same compartment (8). Identity of this compartment has not been elucidated by morphological examination yet. HS fragments with MW 10,000 generated by step 4 remain unchanged for 1$2 \mathrm{hr}$ before they undergo the next wave of endoglycosidic degradation (step 5) which generates HS fragments with an average MW $\sim 5,000$. The second glycosidic cleavage also appears to involve a heparanase. However, there are clear distinctions between heparanase activities observed in steps 4 and 5. Chloroquine completely blocks the later step (2), suggesting the requirement of acidification (either the compartment itself is acidic or acidification is required for the vesicular transport).

In addition, step 4 appears to represent a result of limit digestion (i.e., HS fragments with MW 5,000 are not generated for 1-2 h). Therefore, it can be concluded that (i) step 4 and step 5 degradation occur in two functionally distinct cellular compartments, and (ii) two distinct heparanases with different $\mathrm{pH}$ optimum and substrate specificity may be involved (or the conformational changes in heparanase and/or HS at lower $\mathrm{pH}$ resulted in generation of a new cleavage specificity). Interestingly, HS fragments with MW 5,000 still have a half-life of 3-4 $\mathrm{hr}$ before their complete degradation in the lysosome (step 6). Since the final degradation of HS in lysosomes is rapid and complete, no further degradative intermediates can be observed, indicating that the step 5 degradation occurs yet in a compartment functionally distinct from the classic lysosome.

Metabolic studies have indicated that step-wise degradation of HSPG (steps 4 and 5) occurs in non-lysosomal compartments. However, so far, morphological studies have not identified these compartments. A part of the reasons maybe due to difficulties in fixing free HS chains in the cell. Subcellular fractionation procedures have also been attempted to identify the compartment, and there has been some reports that HS fragments were cofractionated in high density fractions with lysosomes. However, due to technical limitations inherent to subcellular fractionation techniques, such as difficulties in identifying uncharacterized compartments and obtaining quantitative results, identification has been difficult.

Intracellular degradation processes involving heparanase have been found in wide variety of cells. Consequently, in a steady state, most cells have both intact HSPG on the cell surface and free HS fragments intracellularly. Amounts
45)による分解を受け、その分子量を約 $3 \sim 4$ 万から平均約 1 万 にまで減じる(第 4 段階)。この段階はクロロキンを投与しても 阻害されないことから、細胞内で中性 $\mathrm{pH}$ に近い条件を持った小 器官内での分解過程と考えられる。また、この分解に関与する ヘパラネースの至適 $\mathrm{pH}$ が中性付近であることも、この分解過程 がエンドソームなどの前ライソソーム細胞内小器官内での分解 過程であることを支持する。形態学的、細胞小器官分画法など を用いた実験でもこれがどの細胞小器官に相当するものかは明 らかになっていない。コアタンパクの分解はへパラネースによ る糖鎖分解に先行して、かつ機能的には異なった細胞内小器官 で起こるというデータがある(8)。この分子量約 1 万のへパラン 硫酸鎖は $3 \sim 4$ 時間の半減期を持って次の分解過程を受ける(第 5 段階)。この分解過程も endo- $\beta$-glucuronidase 活性による分解 と考えられている。この分解過程では平均分子量約 1 万のへパ ラン硫酸鎖がさらに平均分子量 5 千程度までに分解される。こ の第 5 段階に関与したへパラネースが第 4 段階に作用したへパ ラネースと同様のものであるかどうかは議論のあるところであ るが、以下のような興味ある観察もなされている。つまり、こ の第 5 段階における分解がクロロキンなどにより完全に阻害さ れるため(2)、この分解過程は第4段階の分解と異なり酸性条件 で起こっていると考えられる(あるいはこの分解過程が起こる小 器官に到達するために酸性化が必要である)。また第4段階の分 解はそのまま進行せずに平均分子量約 1 万のヘパラン硫酸鎖の 状態で一旦 1 2 時間とどまった後に第 5 段階の分解が開始する ことなどである。

従って、第 4 段階と第 5 段階における endo- $\beta$-glucuronidase 分解は、(i)機能的に異なる細胞小器官内(実際には同一の小器官 が時間と共にその性質を変化させている可能性もある)で起こ り、(ii)異なった基質特異性のへパラネースによる分解（異なる 酵素タンパク、あるいは同一の酵素タンパクが $\mathrm{pH}$ 条件の変化 などにより酵素タンパク自体あるいはへパラン硫酸鎖構造変化 のために基質構造特異性が変化した可能性も考えられる)である と結論される。この分解産物も次のライソソームにおける最終 分解過程にいたるまで3〜4時間という半減期をもち、したがっ て、この分解過程も酸性条件ではあるがライソソームとは機能 的に異なる小器官における分解であると考えられる。ライソ ソームに扔ける分解(図中第 6 段階) は糖鎖非還元末端からの exoglycosidaseおよび脱硫酸酵素による分解であり、パルスチェ イス実験でも中間分解産物が検出されないことから急速に進行 し、終了する分解過程と考えられる。さらにこのことは、前段 階において生成された平均分子量約 5 千のヘパラン硫酸鎖が最 終分解過程の起こるライソソームに達する以前(物理的にあるい は機能的に)の細胞小器官に存在することを意味する。ライソ ソーム内でのヘパラン硫酸鎖分解はクロロキンのような典型的 な細胞小器官酸性化抑制剂によって完全に阻害される。ライソ ソームにおけるグライコサミノグライカンの分解に関しては本 稿では割愛するので、ほかの総説を参照いただきたい(46、47)。 ヘパラネース分解の起こる細胞小器官については上記のよ うにエンドソームのような前ライソソーム器官が推察されるが、 電子顕微鏡などを使った形態学的な方法では遊離のへパラン硫 酸鎖の固定が困難なこともありその局在を確かめることが難し 
of these HS species in the cell are determined by biosynthetic rate of HSPG, turnover rate on the cell surface and rates of intracellular degradation.

Biological functions of free HS fragments in the cell have been ambiguous, although there are some relevant observations. One notable observation was with basic fibroblast growth factor (bFGF). bFGF can bind to free HS fragments, and has a relatively long intracellular half-life like HS fragments but unlike other molecules which undergo receptor-mediated endocytosis. This lead to a hypothesis that the binding of bFGF to HS fragment prevents its intracellular degradation, thus elongating intracellular life of bFGF. As a matter fact, a mutated bFGF lacking heparin binding domain, has a much shorter intracellular half-life.

Heparanase has drawn much attention from other field of research as well, namely from oncology field. Some cancer cells (notably melanomas) have been found to produce large amounts of heparanase (42-44), and their metastatic properties seem closely related to levels of the enzyme. Heparanase produced by cancer cells may degrade HSPG in basement membranes, thus assisting them to invade vascular basement membranes and to establish metastases. Also, heparanase could release growth factors bound to HSPG in the extracellular matrix or on the cell surface, thus increasing levels of available growth factors for cancer cells for their growth. These examples illustrate diverse biological functions of HSPG and their involvement in some pathological processes.

Degradation of HS in the lysosome is not discussed in this article, and other review articles should be consulted (46, 47).

\section{E. Other Metabolic Pathways}

In addition to the above described two major intracellular degradation pathways, several other metabolic schemes have been reported in other cell systems. Fransson et al., as discussed in a separate article in this volume, observed that some HSPGs are routed to the golgi apparatus after endocytosis for reutilization (step 7). Another paper reported that some HS chains rich in 2-sulfated glucuronic acid are transported to nucleus (step 8) and may regulate cell proliferation (31). Other cells may degrade HS chains by heparanase on the cell surface (not in the cell) and release HS fragments into medium (34), or some HS fragments generated intracellularly may also be released into medium later $(13,14)$.

\section{F. Conclusion}

The metabolic regulation of HSPGs plays crucial roles in fulfilling biological functions of the molecule. Therefore, elucidation of metabolic processes including intracellular catabolism of HSPG will provide information understanding important biological roles of HSPG.
い。細胞分画法ではライソソームと同様に比較的比重の高い分 画にへパラネース分解を受けたへパラン硫酸鎖の一部が見られ るとの報告があるが、この方法の持つ定量性の困難さ、細胞小 器官の持つ多様性のため同定はやはり困難である。

このようなへパラネースの関与したへパラン硫酸プロテオ グライカンの細胞内分解経路は多くの細胞で共通に観察される。 ヘパラン硫酸プロテオグライカンの細胞表面および細胞内での 代謝回転の速さに応じて、細胞は基本的に細胞表面に分解され ていないへパラン硫酸プロテオグライカン、細胞内には一部分 分解された遊離のヘパラン硫酸鎖を持つことになる。

細胞内の遊離へパラン硫酸鎖の機能に関しては不明な部分 が多いが、例えばFGFが細胞内でもこれらのへパラン硫酸鎖と 結合することが可能であり、FGFがエンドサイトーシスを受け た後細胞内で比較的長時間分解を受けないのはへパラン硫酸鎖 との結合のためではないかとも考えられる。これはへパリン結 合部位を失ったFGFがエンドサイトーシスされた後急速に細胞 内で分解を受けることからも分にうなずけることである。

興味あることに他の分野からもへパラネースに対する関心 が高まっている。即ち、ある種の癌細胞がへパラネースを多量 に産生することが見つかったことで(42-44)、この酵素が特に癌 細胞の転移機構に関連しているらしいことである。癌細胞から 分泌されたへパラネースが血管基底膜のヘパラン硫酸プロテオ グライカンを分解し、転移巣の確立に導くという仮説が立てら れている。また、へパラネースはヘパラン硫酸プロテオグライ カンに結合した成長因子などを放出することができ、癌細胞に 成長因子を供給する役割を持つという仮説もある。いずれもへ パラネースがその本来の作用以外にも多彩な機能を持ち、へパ ラン硫酸の関与した生物学的現象を調節していることを示して いる。

\section{E. その他の代謝経路}

上記の二つ主要な細胞内代謝経路のほかに、一度エンドサ イトーシスされたへパラン硫酸プロテオグライカンが再びゴル ジ装置に輸送され(第 7 段階)生合成過程に再利用されるとの報 告があり、Franssonらにより本特集に詳述されている。またへ パラン硫酸鎖の一部がへパラネースによる部分分解を受けた後、 核に輸送される(第 8 段階)という報告もある。核に輸送される ヘパラン硫酸鎖はグルクロン酸-2- 硫酸を持つ特殊な構造であ り、細胞分裂の調節に関与しているとのデータも提出されてい る(31)。そのほかへパラネースによるヘパラン硫酸が細胞表面で 起こり、部分分解を受けたへパラン硫酸鎖が細胞外に放出され る細胞や(34)、細胞内で作られたヘパラン硫酸の部分分解産物 が細胞外に放出される細胞のある(13,14)ことも報告されている。

\section{F. おわりに}

細胞膜ヘパラン硫酸プロテオグライカンの細胞内代謝は、 この分子の機能および細胞による調節機構の全体像から捕らえ ることが重要であろう。これは多彩なへパラン硫酸プロテオグ ライカンの生物学的機能を知る上で重要な知識を提供する。

東京医科歯科大学歯学部生化学講座 柳下 正樹 


\section{References}

1. Yanagishita, M., and Hascall, V.C.(1984) J. Biol. Chem. 259, 10260-10269

2. Yanagishita, M., and Hascall, V.C. (1984) J. Biol. Chem. 259, 10270-10283

3. Yanagishita, M., and Hascall, V.C. (1985) J. Biol. Chem. 260, 5445-5455

4. Yanagishita, M. (1985) J. Biol. Chem. 260, 11075-11082

5. Yanagishita, M. (1987) Arch. Biochem. Biophys. 251, 287-298

6. Yanagishita, M., and McQuillan, D.J.(1989) J. Biol. Chem. 264,17551-17558

7. Yanagishita, M. (1992) J. Biol. Chem. 267, 9499-9504

8. Yanagishita, M. (1992) J. Biol. Chem. 267, 9505-9511

9. Yanagishita, M., and Hascall, V.C. (1992) J. Biol. Chem. 267, 9451-9454

10. Uhlin-Hansen, L., and Yanagishita, M. (1993) J. Biol. Chem. 268, 17370-17376

11. Hiscock, D., Yanagishita, M., and Hascall, V.C.(1994) J. Biol. Chem. 269, 4539-4546

12. Uhlin-Hansen, L., and Yanagishita, M., Brefeld (1995) Biochem. J. 310, 271-278

13. Takeuchi, Y., Sakaguchi, K., Yanagishita, M., Aurbach, G. D., and Hascall,V.C. (1990) J. Biol. Chem. 265, 13661-13668

14. Takeuchi, Y., Yanagishita, M., and Hascall, V.C. (1992) J. Biol. Chem. 267, 14677-14684

15. Takeuchi, Y., Yanagishita, M., and Hascall, V.C. (1992) Arch. Biochem. Biophys. 298, 371-379

16. Takeuchi, Y., Yanagishita, M., and Hascall, V.C. (1992) J. Biol. Chem. 267, 14685-14690

17. Subramanian, S.V., Fitzgerald, M.L., and Bernfield, M. (1997) J. Biol. Chem. 272, 14713-14720

18. Bienkowski, M.J., and Conrad, H.E. (1984) J. Biol. Chem. 259, 12989-12996

19. Ishihara, M., Fedarko, N.S., and Conrad, H.E. (1986) J. Biol. Chem. 261, 13575-13580

20. Kjellén, L., Pertoft, H., Oldberg, A., and Höök, M. (1985) J. Biol. Chem. 260, 8416-8422,

21. Krüger, U., and Kresse, H. (1986) Hoppe-Seyler's Zeit. Physiol. Chem. 367, 465-471

22. Bârzu,T., Van Rijn, J.L.M.L., Petitou, M., Tobelem. G., and Caen, J. (1987) Thromb. Res. 47, 601-609

23. Iozzo, R. ( 1987) J. Biol. Chem. 262, 1888-1900

24. Bame, K. J. (1993) J. Biol. Chem. 28, 19956-19964

25. Kinoshita, S. (1969) Exp. Cell Res. 56, 39-43

26. Fedarko, N.S., Ishihara M., and Conrad, H. E. (1989) J. Cell. Physiol. 139, 287-294.

27. Edgren, G., Havsmark, B., Jonsson, M., and Fransson, L.- $\AA$. (1997) Glycobiology, 7, 103-112,

28. Fransson, L.- $\AA$., Edgren, G., Havsmark, B., and Schmidtchen, A. (1995) Glycobiology. 5, 407-415,

29. Bernfield, M., Kokenyesi, R., Kato, M., Hinkes, M.T., Spring, J., Gallo, R.L., and Lose, E.J. (1992) Ann. Rev. Cell Biol. 8, 365-393

30. Mertens, G., Van der Schueren, B., Van den Berghe, H., and David, G. (1996) J. Cell Biol. 132, 487-497

31. Ishihara, M., Fedarko, N.S., and Conrad, H.E. (1987) J. Biol. Chem. 262, 4708-4717

32. Oh, E.S., Woods, A., and Couchman J.R. (1997) J. Biol. Chem. 272,11805-11811

33. Hashimoto, O., Nakamura, T., Shoji, H., Shimasaki, S., Hayashi, Y., and Sugino, H. (1997) J. Biol. Chem. 272, 13835-13842

34. Gallagher, J.T., Walker, A., Lyon, M., and Evans, W.M. (1988) Biochem. J. 250,719-726

35. Ögren, S., and Lindahl, U. (1976) Biochem. J. 154, 605-61 1

36. Oosta, G.M., Favreau, L.V., Beeler, D.L., and Rosenberg, R.D. (1982) J. Biol. Chem. 257, 11249-11255

37. Thunberg, L., Bäckström, G., Wasteson, A., Robinson, H. C., Ögren, S., and Lindahl, U. (1982) J. Biol. Chem. 257, 10278-10282

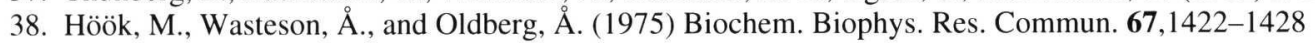

39. Klein, U., and Von Figura, K. (1976) Biochem. Biophys. Res. Commun. 73, 569-576

40. Young, E., and Horner, A.A. (1979) Biochem. J. 180, 587-596

41. Oldberg, Å., Heldin, C.-H., Wasteson, Å., Busch, C., and Höök, M. (1980) Biochemistry 19, 5755

42. Nakajima, M., Irimura T., Di Ferrante, N., and Nicolson G.L. (1984) J. Biol. Chem. 259, 2283-2290

43. Nakajima, M., Irimura. T., and Nicolson, G.L., (1988) J. Cell Biochem. 36, 157-167

44. Jin, L., Nakajima, M., and Nicolson G. L. (1990) Int. J. Cancer 45, 1088-i095

45. Sewell, R. F., Brenchley, P.E.C., and Mallick, N.P. ( 1989) Biochem. J. 264, 777-783

46. Hopwood, J.J. (1989) in Heparin. Chemical and Biological Properties, Clinical Applications (Lane, D.A., and Lindahl, U.,eds.) pp. 191-228, Boca Raton, CRC Press. Inc.

47. Freeman C., and Hopwood, J.J. (1992) in Heparin and Related Polysaccharides (Lane, D.A., Bjÿrk. I., and Lindahl, U.,eds.) Advances in Experimental Medicine and Biology, Vol. 313, pp. 121-134, New York, Plenum Press

Received on March 20, 1998, accepted on March 23, 1998

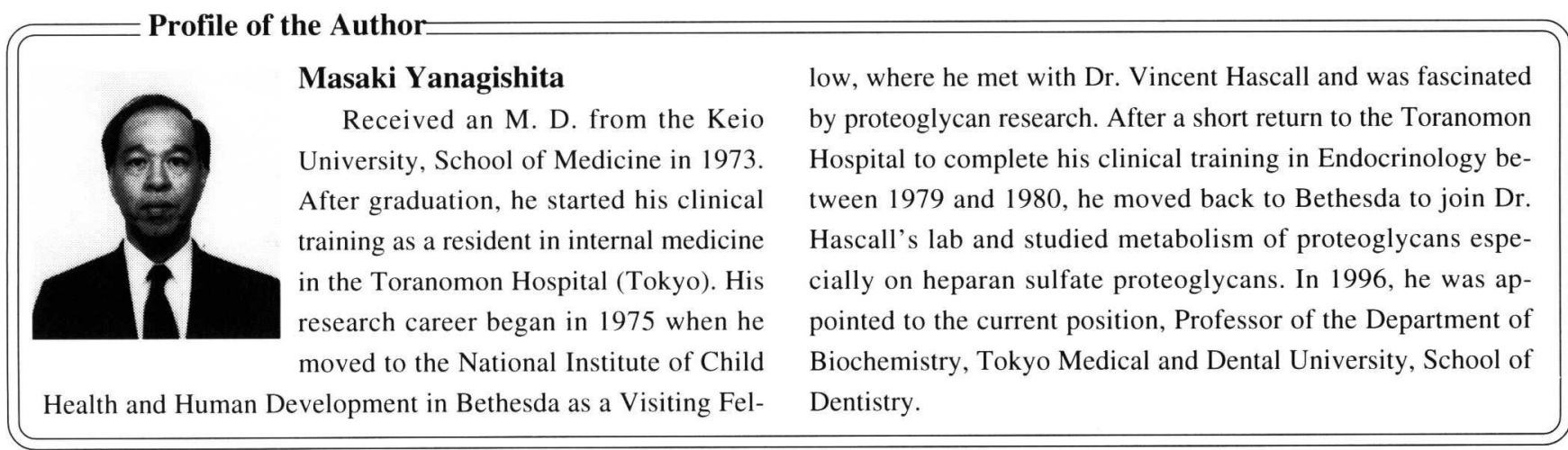

